\title{
Hugh Hefner, the International Academy of Sex Research, and Its Founding President
}

\author{
Richard Green ${ }^{1}$
}

Published online: 27 October 2017

(C) Springer Science+Business Media, LLC 2017

This brief history is provided to the readers of Archives of Sexual Behavior, the official publication of the IASR, who may be unaware of the link.

In 1953, when I was a first year premedical student, Hugh Hefner (1926-2017) published the first issue of PLAYBOY magazine, featuring a nude Marilyn Monroe. PLAYBOY took its place for my study of anatomy alongside GRAY'S.

Twodecades later, when I founded the International Academy of Sex Research, we needed to be incorporated as tax-exempt. Burton Joseph, Executive Director of the Playboy Foundation, arranged this. His letter of September 18, 1973 :

\section{Dear Dick,}

Ihave spoken with Playboy's counsel. They have assigned one of their experienced attorneys to handle the matter of incorporation of the International Academy of Sex Research. I have arranged to have all the costs billed to the Playboy Foundation as our contribution toward the success of the Academy.

Burt served as Treasurer and Legal Advisor. We paid nothing for his services. For years, we were incorporated in Illinois, the home of Playboy. When Burt died, I arranged with Julia Heiman to relocate the IASR for safekeeping at the Kinsey Institute in Indiana.

Our 1975 inaugural meeting in Stony Brook, NY required international scholars to bolster our name. The Playboy Foundation paid for the travel of John Bancroft from Oxford, England.

Playboy helped with sex and gender research. When I transferred my long-term study of cross-gender behaving boys from UCLA to Stony Brook, funding temporarily fell between two stools. The Playboy Foundation bridged the gap. When I began the study of mothers, currently living as lesbians, and their children, Playboy provided seed money. For the first "lesbian mother child custody case," Playboy funded the mother's attorney and her expert witness. We won.

When I discussed my long-term feminine boy study with Hefner at the Playboy Mansion in Los Angeles, he made an astute comment. As I described the three groups of boys, feminine boys becoming gay men, feminine boys becoming straight men, and masculine boys becoming straight men, to him, the most interesting were the feminine boys maturing as straight.

Hef's only daughter, Christie, and I were on panels at professional meetings. Charming, intelligent, and an advocate of sexual rights and the First Amendment promise of free speech, she served as Playboy CEO for 20 years.

The location in Los Angeles of the 100 million dollar Playboy Mansion is on Charing Cross Road. Ironic, then, that when I moved to London to direct the largest transsexual treatment program, it was located at Charing Cross Hospital.

Reactions to Hugh Hefner's death were mixed. Some women writers excoriated him. Brownmiller (2017) wrote "Hugh Hefner Was My Enemy.” But Soh (2017) wrote "We should all thank Hugh Hefner for sexual liberation." A more modulated response was sent to me in an email by a woman writer friend, Jehan Bokhari: "If he has gone to heaven, he was better off where he was."

Acknowledgments Richard Green is Professor of Psychiatry, Emeritus, University of California, Los Angeles, Los Angeles, CA, the Founding President, International Academy of Sex Research, and Founding Editor, Archives of Sexual Behavior.

\footnotetext{
Richard Green

profrgreen@gmail.com

Los Angeles, CA, USA
} 


\section{References}

Brownmiller, S. (2017). Hugh Hefner was my enemy. New York Times. https://www.nytimes.com/2017/09/29/opinion/sunday/hughhefner.html.
Soh, D. (2017). We should all thank Hugh Hefner for sexual liberation. Globe and Mail. https://beta.theglobeandmail.com/opinion/weshould-all-thank-hugh-hefner-for-sexual-liberation/article364337 87/?ref=http://www.theglobeandmail.com\&. 